\title{
Türkiye’nin farklı bölgelerinde otizmli çocuğu olan ailelerin aşılar hakkındaki bilgi düzeylerinin, aşı reddinin sıkı̆̆ının, ve nedenlerinin araştırılması.
}

\section{Investigation on families have autistic children about knowladge level of vaccines, vaccination denial frequency, and reasons of vaccinaiton denial in different regions of Turkey.}

iD Recep Keşli1 ${ }^{1,2}$, iD Yasin Dünya ${ }^{3}$ (iD) Abdulmanoor Zaheer ${ }^{3}$, iD Danyal Rezazadeh Roudkoli³, iD Rukiye Gün³, Mehmet Bardak ${ }^{3}$, iD Esra Zeynep Yücesan ${ }^{3}$, iD Muhammed Rasim Demirayak ${ }^{3}$, iD Fadime Özge Dilcioğlu ${ }^{3}$, iD Fatma

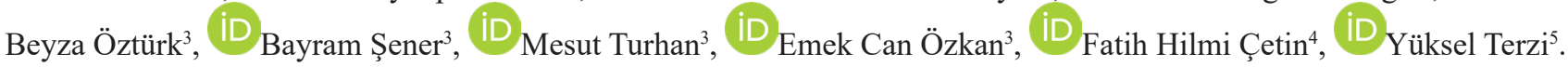

${ }^{1}$ Selçuk Üniversitesi, Otizm Çalışmaları Uygulama ve Araştırma Merkezi (SOTAM), Konya

${ }^{2}$ Selçuk Üniversitesi, Tip Fakültesi, Tıbbi mikrobiyoloji Anabilim Dalı, Konya

${ }^{3}$ Selçuk Üniversitesi, Tıp Fakültesi 2. Sınıf Öğrencisi, Konya

${ }^{4}$ Selçuk Üniversitesi, Tıp Fakültesi, Çocuk ve Ergen Psikiyatri Anabilim Dalı, Konya

${ }^{5}$ Ondokuz Mayıs Üniversitesi, Fen Edebiyat Fakültesi İstatistik Bölümü, Samsun

$\ddot{\mathrm{O} z}$

Amaç: Otizm spektrum bozukluğu (OSB), erken çocukluk dönemlerinde sosyal etkileşim ve iletişim becerilerinde yetersizlik, kısıtlı ilgi alanı ve stereotipik davranış örüntüleri ile karakterize nörogelişimsel önemli bir bozukluktur. Bu çalışmanın amacı OSB tanısı almış çocuğu olan ebeveynlerin aşılar hakkında genel bilgilerini ölçme, aşıya karşı tutumlarını belirleme, aşı karşıtlı̆̆ının oranı ve nedenlerini saptamaktır.

Gereç ve Yöntem: Çalışma, OSB tanılı çocukları olan ebeveynlerden birisi ile, yüz yüze görüşmek sureti ile, anket yaparak gerçekleştirilmiştir.

Bulgular: Elde edilen verilere göre; kontrol grubu ile karşılaştırıldığında, otizmli çocukları olan ebeveynlerin; aşılar hakkındaki bilgi düzeylerinin, ve aşı reddi tercihlerinin daha yüksek olduğu, aşıların içeriklerinden daha çok şüphe duydukları, özellikle canlı virus aşılaması ile otizmin başlaması arasında, zamansal ilişki olduğuna inandıkları belirlenmiştir.

Sonuç: OSB tanılı çocukların rutin çocuk-ergen psikiyatristleri tarafından, rutin kontrollerinde; ailelerin aşılar hakkındaki düşünceleri, kaygıları ve kaçınmaları değerlendirilmelidir.

Anahtar kelimeler: Otizm Spektrum Bozukluğu - etiyoloji - aşılar - bilgi düzeyi - aşı reddi sıklı̆̆1

\section{Abtract}

Objective: Autism spectrum disorder (ASD) is an important neurodevelopmental disorder, that manifests itself in the decline of the social interaction and communication, learning, and language skills in early childhood. The aim of this study was to measure the general knowledge of the parents have children diagnosed with ASD, to determine their attitudes towards vaccination, to determinate the rate and reason of anti- vaccination.

Material and Methods: The study was carried out by conducting a survey, by means of talking face to face one of ASD diganosed children's parents.

Results: According to the data obtained, when compared to the control group's and ASD parents; have higher level of knowledege about vaccines, and preference of vaccination refusal, have higher rate of doubt related with Ingredients of vaccines, and believe that; there was a temporarly connection between onset of autism, and especially live viral vaccines.

Conlcusion: Thoughts, worries, and drawbaks of the families should be evaluated during the routine control of cihildren dignosed as ASD, by child and adolescent psychatrists.

Keywords: Autism Spectrum Disorder,. - etiology - vaccines - knowledge level - vaccination refusal frequency

Yazışma Adresi: Recep Keşli, Selçuk Üniversitesi, Otizm Çalışmaları Uygulama ve Araştırma Merkezi (SOTAM), Tıp Fakültesi, Tıbbi Mikrobiyoloji Anabilim Dalı, Selçuklu, Konya.

E-Posta: recepkesli@gmail.com

Alınma Tarihi: 28.12.2020 / Kabul Tarihi: 21.06.2021 / Yayımlanma Tarihi: 20.09.2021

Otizm, aşılar hakkındaki bilgi düzeyi, aşı reddi sıłlığı, nedenleri - Keşli ve ark. 
Otizm tek bir hastalık olmayıp, otizm spektrum bozukluğu (OSB) adı ile tanımlanan, erken çocukluk çağında belirti veren, beyin gelişimi ile ilgili nörogelişimsel bir bozukluktur, sosyal etkileşim, sözel ve sözel olmayan iletişim alanlarında bozulma, sınırlı ve yineleyici ilgi ve davranışlar ile seyretmektedir. Hastalığın doğasının hafiften ağıra doğru bir yelpaze içerisinde seyrettiği doğasına vurgu yapmak amacıyla, Rett bozukluğu tanının kapsamı dışında bırakılarak, yaygın gelişimsel bozukluklar ifadesi altındaki hastalıklar birleştirilmiş ve "otizm spektrum bozukluğu” adını almıştır. Bu tanım otistik bozukluk/çocukluk otizmi, yaygın gelişimsel bozukluk, çocukluğun dezintegratif ozukluğu ve Asperger Sendromu'nu kapsamaktadır (1).

Amerika Birleşik Devletleri CDC (Center Disease Control, Hastalık Kontrol ve Önleme Merkezi)'nin son verilerine göre sıklığ 1000 de 18.5 oranında olup, erkeklerde kızlardan 4.3 kat daha sik görülmektedir (2). OSB, nedeni henüz tam olarak aydınlatılamamış bir durum olup, çoklu genetik faktörler ve gen-çevresel etmenlerin etkileşimi rol oynamaktadır. İkiz eşi ve kardeşi OSB tanısı alan, ebeveyn yaşı ileri olan, premature veya düşük doğum ağırlığı ile doğan, annenin hamileyken geçirdiği enfeksiyona karşı bağışıklık tepkisi olan, OSB dışı herhangi bir genetik, psikiyatrik, nörolojik veya gelişimsel hastalık tanısı alan çocuklarda OSB görülme sıklığı artmaktadir (3-8).

Yıllar içinde otizm tanısı alan vaka sayısındaki artış nedeniyle pek çok faktör araştırılmış olup; bunlar arasında özellikle aşılar içerisinde bulunan tiomersal da bulunmaktadır. Ancak yapılan çalışmalarda, bu zamana kadar uygulamadaki herhangi bir aşının otizm yaptığ gösterilememiştir (9). Yapılan çalışmalar göstermiştir ki, tiomersal içeren ve içermeyen aşı uygulanan çocuklar arasında OSB gelişimi açısından fark yoktur. Ayrıca aşıdan tiomersal çıkarıldıktan sonraki yıllarda otizm görülme sıklığında da artış görülmüştür. Tiomersal otizme yol açsaydı, aşıdan çıkarıldıktan sonra otizm gelişme oranında düşüş olması beklenirdi (10).

Aşıların otizmle ilgisi olduğunu savunan kişilerin bir diğer iddiası ise KKK/MMR (Kızamık-Kızamıkçık-Kabakulak/Mumps Measles Rubella) aşısının otizme yol açtığıdır. Bu konuyla da ilgili dünyada pek çok araştırılma yapılmış, ancak hiçbirinde aşının doğrudan otizme yol açtığı gösterilememiştir. Dünya Sağlık Örgütünün son bildirisinde KKK aşısının otizmle ilişkisi olmadığı tekrar vurgulanmıştır $(11,12)$.

Yaptığımız çalışmanın amacı Türkiye'nin dört farklı coğrafi bölgelerinde (İç Anadolu Bölgesi, Güneydoğu Anadolu Bölgesi, Marmara Bölgesi, ve Karadeniz Bölgesi), otizm tanısı almış bireylerin ebeveynleri ile görüşerek onların demografik verileri, aşılar hakkındaki bilgi düzeyleri, aşı reddi ve aşılar ile otizm arasında ilişki olup olmadığı konusundaki düşünceleri hakkında ayrıntılı bilgi edinmektir. Bu çalışmayı İstanbul, Konya, Bursa, Samsun, Diyarbakır büyükşehirlerinde, geniş katılımlı ve farklı bölgelerden insanlarla yaparak en isabetli sonuçlara ulaşmayı hedefledik.
$\mathrm{Bu}$ çalışmada; otizm tanılı bireylerin ebeveynlerinin aşılar hakkındaki bilgi düzeyleri ile aşı reddi sıklığının, ve aşı reddi konusundaki tutum ve davranışlarının (aşı reddinin gerekçelerinin) anket yolu ile belirlenmesi amaçlanmıştır. Çalışmada Selçuk Üniversitesi Tıp Fakültesi Dönem 2 öğrencileri KDT 1C grubu tarafından hazırlanan anketler kullanılmıştır. Çalışma üç aylık sürede (Mart-Mayıs 2020) otizmli, ve sağlıklı kontrol grubunu oluşturan bireylerin ebeveynleri ile yüz yüze görüşerek yürütülmüştür. Çalışmada kullanılan anket; demografik veriler, aşılar hakkındaki bilgi düzeyleri, ve aşı reddi konusundaki tutum ve davranışlarının belirlenmesine yönelik olmak üzere, başlica üç ana bölümden oluşturulmuştur.

Denek grubu: Çalışma grubu; otizm spektrum bozukluğuna sahip çocukların aileleri, kontrol grubu herhangi bir hastalık tanısı konulmamış çocukların ailelerinden meydana getirilmiştir. Otizm ile ilgili bazı dernek ve vakıfların katkı ve yardımları ile ailelere ulaşılmış, anket hakkında aileler bilgilendirilmiş, ve katılmak isteyen ebeveynler çalışmaya dahil edilmiştir. Deney ve kontrol grupları seçilirken aralarında yaş ve cinsiyet farkı bulunmamasına, eşit sayıda olmasına dikkat edilmiştir.

Etik kurul onayı: Çalışma ve çalışmada kullanılan anketler Selçuk Üniversitesi Tıp Fakültesi Girişimsel Olmayan Etik Kurul Başkanlığı tarafından onaylanmıştır (2020/73).

Anketler Türkiye'nin dört farklı farklı bölgelerine ait ait beş büyük şehirlerden (İstanbul, Bursa, Diyarbakır, Samsun) rastgele seçilmiş 125 'i otizm tanılı ve125'i de sağlıklı çocuğa sahip olan toplam 250 ebeveyn ile yapılmıştır. Anket soruları tüm ebeveynlere yüz yüze görüşme yöntemiyle sorulmuş ve cevaplar aynı kişi tarafından kaydedilmiştir. Uygulanan anket formu bu bölümün sonuna eklenmiştir.

Araştırmanın bağımlı değişkenleri; ailelerin otizm tanısı almış çocuğunun olup olmaması ve ebeveynlerin aşılar hakkındaki bilgi düzeyleri ve tutumları, bağımsız değişkenler ise, ebeveynlerin yaşı, mesleği, eğitim durumu, ailenin geliri gibi durumlar olarak değerlendirilmiştir.

Veriler, sosyo-demografik özellikleri tanımlamaya, aşılar hakkındaki bilgi düzeylerini belirlemeye, ve aşı reddi konusundaki tutumlarını değerlendirmeye yönelik, elli dokuz adet sorudan oluşan anketin uygulanması sonucu elde edilmiştir.

İstatistiksel analizler: Çalışmada elde edilen bulgular değerlendirilirken, istatistiksel analiz için; Oran testi, nitel değişkenler arasındaki ilişki durumu için Pearson Ki-kare ve Yates Ki-Kare tesi, normal dağılış göstermeyen iki grup karşılaştırmaları için MannWhitney U testi kullanılmıştır. Ölçeğin güvenirlilik ve geçerlilik analizine bakılmıştır. Veriler IBM SPSS 20.0 programında analiz edilmiştir. $\mathrm{p}<0,05$ istatistiksel olarak anlamlı kabul edilmiştir.

Aşı güvenilirlik ölçeği: Çalışmada İrem Nur Özdemir tarafından 
yüksek lisans tezi aşı güvenilirlik ölçeği kullanılmıştır $(13,14)$.

\section{Aşı güvenilirlik ölçeği}

Cronbach's alfa $=0,750$ bulunmuş ve ölçek $\% 75$ oranında güvenilir bulunmuştur. Açıklayıcı faktör analizi ile ölçeğin tek faktörde toplandığ ve bu faktörün ölçeğin \%65'inin açıkladığı görülmüştür. K.M.O. $=0,842$; Bartlett's testi $\mathrm{p}=0,000<0,01$ bulunmuştur. $\mathrm{Bu}$ değerler ölçekteki örnek sayısının yeterli ve değişkenler arasında önemli bir ilişki olduğunu göstermiştir. Ölçek konunun uzmanlarına anketten önce inceletilmiş ve Türkçe geçerliliğine karar verilmiştir (14).

\section{Aşı reddinin gerekçeleri ölçeği}

Cronbach's alfa $=0,895$ ve ölçek $\% 89,5$ oranında güvenilir bulunmuştur. Açıklayıcı faktör analizi ile ölçeğin tek faktörde toplandığ1 ve bu faktörün ölçeğin \%55'inin açıkladığ görülmüştür. K.M.O. $=0,725$; Bartlett's testi $\mathrm{p}=0,000<0,01$ bulunmuştur. $\mathrm{Bu}$ değerler ölçekteki örnek sayısının yeterli ve değişkenler arasında önemli bir ilişki olduğunu göstermiştir. Ölçek konunun uzmanlarına anketten önce inceletilmiş ve Türkçe geçerliliğine karar verilmiştir.

\section{Bulgular}

Türkiye'nin Farklı Bölgelerinde otizmli çocuğu olan ailelerin aşılar hakkında bilgi düzeylerinin, aşı reddi sıklığının, ve nedenlerinin araştırılmasını amaçlayan bu çalışmaya toplam 250 kişi (125 otizm, 125 kontrol grubu) katılmıştır. Çalışmaya katılan bireyler arasında otizmli çocuğu olan ailelerin çocuklarının \%20,8'i erkek \%79,2'si kız çocuğudur. Çalışmaya katılan ailelerin otizmli çocukların cinsiyeti büyük oranda kızdır.

Çalışmaya katılan 250 kişinin $\% 48,8$ 'i anne ve yüzde $\% 51,2$ 'si babadır. Çalışmaya katılan anne ve babaların \%17,6'sı akraba olduklarını belirtmişlerdir. Annelerin \%19,6'sı ilkokul mezunu \%18'i ortaokul mezunu \%32'si lise mezunu ve \%62,4'ü ise lisans veya lisansüstüdür. Çalışmaya katılan annelerin $\% 56,4$ 'ü ev hanımı \%7,6's1 işçi \%21,2'si memur \%10,8'i özel sektör \%4'ü ise diğer sektörlerde çalışmaktadır. Babaların \%11,2'si ilkokul, \%16'sı ortaokul \%24,4'ü lise ve $\% 48,4$ 'ü lisans veya lisansüstü mezunudur. Çalışmaya katılan babaların \%38,4'ü memur, \%26,8'i işçi, \%12,8'i emekli, \%8'i esnaf ve $\% 10,8$ 'i diğer mesleklerde çalışmaktadır \%3,2'si işsizdir.

Çalışmaya katılan otizmli çocuğu olan ailelerin çocuklarının \%20,8'i erkek, \%79,2'si kadındır. Aynı şekilde otizmli çocuğu olan ailelere "Ailenizde aynı tanıyı alan başka hasta var mı?" diye sorulduğunda \%18,8'i evet cevabını vermiş \%81,2'si hayır cevabını vermiştir. Akrabalarındaki oran da bu orana yakındır.

Çalışmaya katılan 250 kişiden \%89,9'unun sosyal güvencesi var $\% 10,4$ 'ünün ise yoktur. \%32'lik kısmın aylık geliri 3000 TL'den az \%25,2'lik kısmın 3000-5000 TL arasında \%18,4'lük kısmın 5000-7000 TL arasında, \%14'lük kısmın 7000-9000 TL arasında ve $\% 10,4$ 'lük kısmın aylık geliri ise 9000 TL' den fazladır.
Kişilerin \%15,6's1 ilçede \%84,4'ü ilde ikamet etmektedir ve \%45,6's1 kirada, \%54,4'ü kendi evinde oturmaktadır.

Çalışmaya katılan 250 kişiden \%42,8'i aşıların yan etkisi olduğunu \%23,6's1 olmadığını düşünmektedir.\%33,6 ise bilmiyorum cevabını vermiştir. Otizm ile aşı ilişkisi sorulduğunda \%26 evet cevabını vermiştir. Ailelerin \%84'ü Sağlık Bakanlığı'nın önerdiği tüm aşıları çocuğuna yaptırmış \%7,6‘s1 eksik aşıları olduğunu söylemiş \%8,4'ü ise hatırlamamıştır.

Aş1 güvenilirlik ölçeği $\% 74,5$ oranında güvenilir bulunmuştur (Cronbach's alpha=0,745). Aş1 reddinin gerekçeleri ölçeği ise \%97,4 oranında güvenilir bulunmuştur (Cronbach's alpha=0,974). Ölçek çalışmasında örneklem sayısı $(\mathrm{n}=250)$ yeterlil bulunmuştur (KaiserMeyer-Olkin=0,934). Faktör analizi sonucunda ise aşı reddi gerekçesi ölçeği tek faktörde toplanmış ve bu faktör toplam varyansın \%69,8'ini açıklamıştır.

Tablo 1. Aş1 güvenilirlik ölçeğinin gruplara göre analizi

\begin{tabular}{lccccc}
\hline Grup & \multicolumn{5}{c}{ Așı Güvenilirlik Ölçeği } \\
& Minimum & Maximum & Range & Medyan & p \\
\hline Kontrol & 1,50 & 9,75 & 8,25 & 7,25 & $0,006^{*}$ \\
Hasta & 1,25 & 10,00 & 8,75 & 6,38 & \\
\hline
\end{tabular}

\%5 önem düzeyinde kontrol grubu ile otizm grubunun aş1 güvenilirlik ölçeği anlamlı bulunmuştur. Otizm grubundakiler aşı hakkında kontrol grubuna göre daha olumsuz düşünmektedirler.

Tablo 2. Aş1 reddi gerekçeleri ölçeğinin gruplara göre analizi

\begin{tabular}{|c|c|r|r|r|r|r|}
\hline \multirow{2}{*}{\multicolumn{2}{|c|}{}} & \multicolumn{5}{|c|}{ AŞI REDDİ GEREKÇELERİ } \\
\cline { 2 - 7 } \multicolumn{2}{|c|}{ Minimum } & Maximum & \multicolumn{1}{c|}{ Range } & \multicolumn{1}{c|}{ Median } & \multicolumn{1}{c|}{$\mathrm{p}$} & \\
\hline \multirow{2}{*}{ Grup } & Kontrol &, 06 & 1,56 & 1,50 & 1,39 & 0,248 \\
\cline { 2 - 8 } & Otizm &, 06 & 2,00 & 1,94 & 1,39 & \\
\hline
\end{tabular}

Aş1 reddi gerekçesi bakımından kontrol ile hasta grubunda istatistiksel olarak anlamlı bir farklılık yoktur $(\mathrm{p}>0,05)$. 
Tablo 3. Aş1 reddine en sık neden olan gerekçelerin analizi

\begin{tabular}{|c|c|c|c|c|c|c|}
\hline & & \multicolumn{4}{|c|}{ Grup } & \multirow[b]{3}{*}{$\mathrm{p}$} \\
\hline & \multicolumn{2}{|c|}{ Kontrol } & \multicolumn{2}{|c|}{ Otizm } & & \\
\hline & Count & $\begin{array}{l}\text { Row } \\
\text { N\% }\end{array}$ & Count & $\begin{array}{l}\text { Row } \\
\mathrm{N} \%\end{array}$ & & \\
\hline S1 Așı reddine & Evet & 17 & $36,2 \%$ & 30 & $63,8 \%$ & $0,003^{*}$ \\
\hline taraftar misınz? & Hayir & 103 & $61,7 \%$ & 64 & $38,3 \%$ & \\
\hline S2 Aşıların & Evet & 55 & $42,0 \%$ & 76 & $58,0 \%$ & $0,000^{*}$ \\
\hline $\begin{array}{l}\text { içeriği hakkında } \\
\text { şüpheliyim. }\end{array}$ & Hayir & 67 & $70,5 \%$ & 28 & $29,5 \%$ & \\
\hline S3 Aşıların & Evet & 56 & $45,9 \%$ & 66 & $54,1 \%$ & $0,006^{*}$ \\
\hline $\begin{array}{l}\text { içeriğinde zararlı } \\
\text { maddeler (cıva, } \\
\text { alüminyum } \\
\text { vb.) olduğunu } \\
\text { düşünüyorum. }\end{array}$ & Hayır & 66 & $64,1 \%$ & 37 & $35,9 \%$ & \\
\hline S4 Așılarıın & Evet & 22 & $26,5 \%$ & 61 & $73,5 \%$ & $0,000^{*}$ \\
\hline $\begin{array}{l}\text { içeriğinin farklı } \\
\text { hastalık/ hastalıkları } \\
\text { tetiklediğini } \\
\text { düşünüyorum. }\end{array}$ & Hayir & 99 & $70,7 \%$ & 41 & $29,3 \%$ & \\
\hline S5 Așıların ticari & Evet & 43 & $44,3 \%$ & 54 & $55,7 \%$ & $0,004^{*}$ \\
\hline $\begin{array}{l}\text { amaçlar için } \\
\text { üretilip satıldığı̆ıı } \\
\text { düşünüyorum. }\end{array}$ & Hayır & 77 & $63,6 \%$ & 44 & $36,4 \%$ & \\
\hline S6 Aşılyla korumak & Evet & 26 & $33,8 \%$ & 51 & $66,2 \%$ & $0,000^{*}$ \\
\hline $\begin{array}{l}\text { yerine hastalğı̆ } \\
\text { geçirerek bağışılık } \\
\text { kazanmanın daha } \\
\text { doğru olduğuna } \\
\text { inanıyorum. }\end{array}$ & Hayır & 94 & $68,6 \%$ & 43 & $31,4 \%$ & \\
\hline S7 Aşı yerine & Evet & 18 & $30,0 \%$ & 42 & $70,0 \%$ & $0,000^{*}$ \\
\hline $\begin{array}{l}\text { bitkisel ürünlerin } \\
\text { daha faydalı } \\
\text { olduğunu } \\
\text { düşünüyorum. }\end{array}$ & Hayır & 103 & $66,0 \%$ & 53 & $34,0 \%$ & \\
\hline S8 Çocukların & Evet & 35 & $42,7 \%$ & 47 & $57,3 \%$ & $0,003^{*}$ \\
\hline $\begin{array}{l}\text { bağı̧şılık sistemleri } \\
\text { daha tam olarak } \\
\text { gelişmediği için } \\
\text { aşıların çocuklara } \\
\text { zarar verdiğini } \\
\text { düşünüyorum. }\end{array}$ & Hayır & 86 & $63,2 \%$ & 50 & $36,8 \%$ & \\
\hline
\end{tabular}

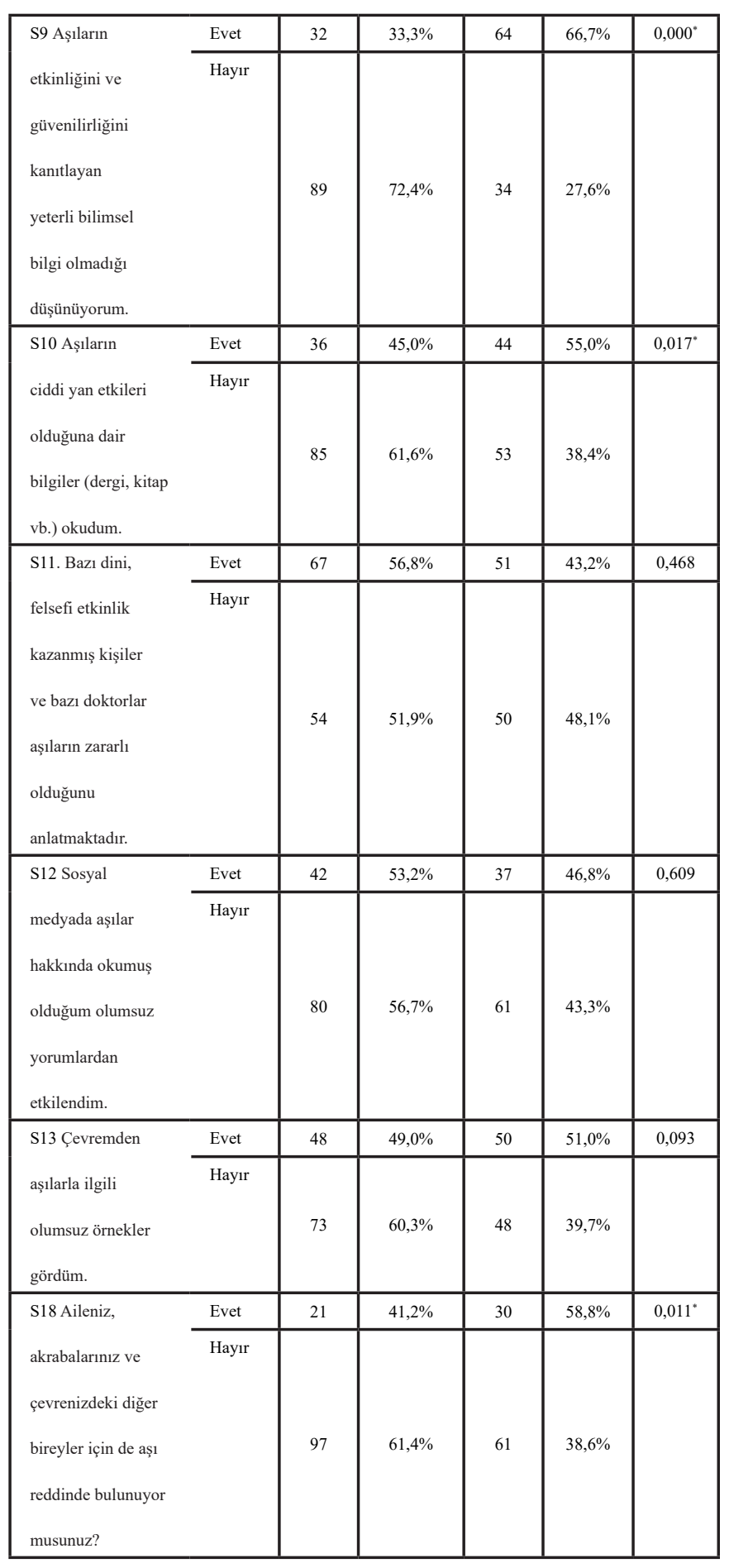

*\%5 önem düzeyinde istatistiksel olarak anlamlıdır.

Aş1 reddine taraftar olma durumu (S1) ile grup (kontrol-otizm) arasında anlamlı farklı1ık bulunmuştur Otizmli çocuğu olan ebeveynlerin aş1 reddinde bulunma oranı $(\% 63,8)$ kontrol grubuna $(\% 36,2)$ göre daha fazladır $(\mathrm{p}=0,003<0,05)$.

Anket sorularını cevaplayan katılımcıların aşıların içeriği hakkında şüpheliyim (S2) kısmına otizmli çocuğu olan ailelerin \%73,1'inin(76) evet \%26,9'unun (28) hayır cevabı verdiği görülmüştür. Kontrol grubunda ise bu oran \%45,1'e (55) \%54,9'dur (67). Otizmli çocuğu olan ebeveynler kontrol grubuna göre aş1ların içeriğinden daha yüksek oranda şüphe duymaktadır ( $\mathrm{p}=0,000<0,01)$.

Otizm, aşılar hakkındaki bilgi düzeyi, aşı reddi sıklığı, nedenleri Keşli ve ark. 
Çalışmaya katılan otizmli çocuğu bulunan ailelerin \%64,1'i (66) aşıların içinde zararlı madde olduğunu düşünmektedir. Bu oran kontrol grubunda \%45,9 (56) olarak gözlemlenmiştir. Otizmli çocuğu olan ebeveynler kontrol grubuna göre daha yüksek bir oranda aşıların içeriğinde zararlı madde olduğunu düşünmektedir $(\mathrm{p}=0,006<0,05)$.

Anket sorularını cevaplayan otizmli çocuğu olan ebeveynlerin \%59,8'i (61) aşının içeriğinin farklı hastalıkları tetiklediğini düşünüyorken bu oran kontrol grubunda \%18,2(22) olarak hesaplanmıştır. Otizmli çocuğu olan ebeveynler daha yüksek bir oranda aşıların farklı hastalıkları tetiklediğini düşünmektedir $(\mathrm{p}=0,000<0,01)$.

Çalışmaya katılan otizmli çocuğu olan ebeveynlerin \%55,1'i(54) aşıların ticari amaçlar için üretilip satıldığına inanıyordur. Bu oran kontrol grubunda \%35,8 (43) olarak hesaplanmıştır. Otizmli çocuğu olan ebeveynler kontrol grubuna göre daha yüksek bir oranda aşıların ticari amaçla satıldığına inanmaktadır $(\mathrm{p}=0,004<0,01)$.

Çalışmaya katılan otizmli çocuğu olan ebeveynlerin \%54,3'ü (51) aşıyla korunmak yerine hastalığ daha doğru olduğunu inanırken kontrol grubunda bu oran \%21,7'dir (26). Otizmli çocuğa sahip aileler daha yüksek bir oranda hastalığı geçirerek bağışıklık kazanılacağına inanmaktadır $(\mathrm{p}=0,000<0,01)$.

Çalışmaya katılan otizmli çocuğu olan ebeveynlerin \%44,2'si (42) aş1 yerine bitkisel ürünlerin daha faydalı olduğunu düşünürken kontrol grubunda bu oran yalnızca \%14,9'dur (18). Otizmli çocuğa sahip ebeveynler kontrol grubuna göre daha yüksek bir oranda bitkisel ürünleri aşılardan daha yararlı görmektedir( $(\mathrm{p}=0,000<0,01)$.

Çalışmaya katılan otizmli çocuğu olan ailelerin "Aşsların etkinliğini ve güvenilirliğini kanıtlayan yeterli bilimsel bilgi olmadığını düşünüyorum” kısmına \%65,3 (64) oranla evet cevabını vermiştir. Kontrol grubunda bu oran \%26,4' tür(32). Otizmli çocuğa sahip ebeveynler kontrol grubuna göre daha yüksek bir oranda aşıların güvenirliğini kanıtlayan belge olmadığını düşünmektedir $(\mathrm{p}=0,000<0,01)$.

Anket sorularını cevaplayan katılımcılardan aileniz, akrabalarınız ve çevrenizdeki diğer bireyler için de aşı reddinde bulunuyorum şeklinde yanıt veren otizmli çocuğa sahip ebeveynlerin oran1 \%33 (30) iken bu oran kontrol grubunda $\% 17,8$ 'dir (21). Otizmli çocuğu olan ailelerde ve kontrol grubunda fark istatistiksel olarak anlamlıdır $(\mathrm{p}=0,011<0,05)$. Otizmli çocuğa sahip ebeveynler kontrol grubuna göre daha yüksek bir oranda çevresi içinde aşı reddinde bulunduğunu söylemektedir.

Çalışmaya katılan bireylere otizm ile aşı arasında ilişki olup olmadığ1 sorulduğunda otizmli çocuğu olan ebeveynler \%33,6 oranında evet yanıtı vermişlerdir. Kontrol grubu ise \%18,4 oranında evet yanıtı vermiştir. Otizmli çocuğu olan ebeveynler aşı ile otizm arasında kontrol grubuna göre daha büyük oranda bağlantı kuruyor $(\mathrm{p}=0,001<0,05)$.

Anket sorularını cevaplayan katılımcılara aşıların yan etkisi olarak otizm seçeneğini işaretleyenlerin oranı otizmli çocuğa sahip ebeveynlerde $\% 15,8$ iken kontrol grubunda $\% 5,3$ e kadar düşmüştür. Otizmli ebeveynler kontrol grubuna göre daha yüksek bir oranda aş1ların otizme sebep olduğunu düşünmektedir $(p=0,003<0,05)$.

\section{Tartışma ve Sonuç}

çalışmamız Türkiye'nin dört farklı coğrafi bölgesinde (İç Anadolu Bölgesi, Güneydoğu Anadolu Bölgesi, Marmara Bölgesi, ve Karadeniz Bölgesi) bulunan beş büyük şehirde (Konya, Diyarbakır, İstanbul, Bursa, ve Samsun) otizm tanısı almış bireylerin ebeveynleri ile görüşülerek yürütülmüştür.

Katılımcılara sorulan sorularda aş1 reddi taraftarlığ $1 \% 31,9$ oranla otizmli çocuğu olan ailelerde daha sık karşılaşılmıştır. Özellikle bu ailelerin \%59,8 oranında aşı içeriğinin farklı hastalıkları tetiklediği şüphesi ve $\% 42,4$ oranında yan etkiler oluşturduğu gerekçesiyle aile içi ve çevresi için karşıtlığı gözlenmiştir. Otizmli çocuğu olan ebeveynlerin yüksek bir oranda aşının yan etkisi olduğu ve bu yan etkinin özellikle otizm olduğuna inandığı ortaya konulmuştur. Çalışmamızda aşı reddi oranının otizmli ailelerde daha sık karşılaşılmasının muhtemel sebepleri aşıların ciddi yan etkileri olduğuna dair eksik ya da hatalı bilgilerin çokluğu, aşıların etkinliğini ve güvenilirliğini kanttlayan bilimsel bilgilere yeteri kadar ulaşılamaması olarak görülmektedir.

Çalışmamızda Otizmli çocuğa sahip ebeveynler \%64,1 oranında aşı içinde zararlı maddeler olduğunu düşündükleri ve \%73,1'inin aş1 içeriği hakkında şüphe ettikleri gözlenmiştir. Fakat otizmli ve otizmsiz çocukların aşılardaki tiomersal maruziyetinin karşılaştırıldığ Price CS ve arkadaşlarına ait bir çalışmada, tiomersal maruziyeti açısından farklılık bulunmadığı net bir şekilde ifade edilmiştir (15). Çalışmamızda aşı içeriği hakkında şüphe edilmesinin sebepleri aşıların faydalarının yeteri kadar bilinmemesi ve aşıların koruduğu hastalıklar hakkında yetersiz bilgi düzeyleri gösterilebilir. Aşıların otizmle ilgisi olduğunu savunan kişilerin bir diğer iddiası ise $\mathrm{KKK}$ (Kızamık-Kızamıkçık-Kabakulak) otizme yol açtığıdır.

Hiçbir epidemiyolojik çalışmada KKK aşısı alan çocuklarda fenotipik olarak farklı bir otizm formunun varlı̆̆ına veya KKK aşısı aldıktan sonra otistik çocuklarda başlangıç semptomlarının kümelenmesine dair herhangi bir kanıt bulunamamıştır (16).

Çalışmaya katılan bireyler arasında otizmli çocuğu olan ve aşı reddine taraftar olan ebeveynlerin \%89.3'ünün çocuğun otizm tanısının, aş1 yaptırdıktan belirli bir süre sonra konulduğu bu sebeple otizmin aşı ile bağlantılı olduğu düşüncesinin aşı karşıtlığında büyük bir rol oynadığı gözlenmiştir. Çalışmadan elde ettiğimiz sonucu destekler nitelikte, otizm spektrum bozukluğu olan çocukların küçük kardeşlerindeki aş1lama durumunu inceleyen Zerbo ve ark. (17), tarafindan yürütülen bir çalışmada, OSB'li çocukların ve küçük kardeşlerinin genel popülasyona göre düşük oranda aşılandığı göstermiş, özellikle bu farkın temelinde ebeveynlerin, aşıların çocuklarının OSB'ye katkıda bulunduğu gerekçesiyle aşıyı reddetmelerinden kaynaklı olduğunu ifade etmiştir. 
Benzer olarak, Çıklar ve ark. (18), tarafindan hazırlanan araştırma makalesinde geçen, ABD'de 2006 yılında yapılan Benin ve ark. (19), çalışmasında anneler benzer şekilde aşı-otizm ilişkisinin aşılama konusunda endişeye neden olacak bir sebep olarak gördüklerini belirtmiştir. Çalışmamızda gözlemlenen aşı-otizm bağlantısını kabul eden ebeveynlerin mesleki açıdan imkanlarının düşük olması, çalışma oranlarının azlığı, düşük ekonomik şartlar sebep gösterilebilir.

Çalışmaya katılıp aşı reddine taraftar olanların \%88.5'inin canlı virüs aşısının otizme sebebiyet verdiğini düşündüğü ortaya konmuştur ve bu oran içerisinde otizmli çocuğa sahip ebeveynler büyük bir sıklık göstermektedir. Fakat bilinmektedir ki; 1998 tarihinde ilk kez Wakefield ve ark.(20) tarafindan Lancet'te yayınlanan rapor sonrası KKK ve otizm ilişkisinin olmadığını kanıtlayan bir çok epidemiyolojik çalışma yapılmıştır (21-23). Bu raporun tekrarlanan bulgulara dayanmamasından kaynaklı olarak geri çekilmesine sebep olmuştur. Bu çalışmalardan ilki 1999 yılında yine Lancet'te yayınlanan Taylor ve ark. na ait çalışmada 1988'de İngiltere'de KKK uygulamasının otizme neden olup olmadığı analiz edilmiştir. Aşının uygulanmaya başlanmasından sonra otizm insidansında artış gözlenmediği görülmüştür (24). Aynı zamanda Ulusal Sağlı ve Nüfus hizmetlerinin verileri kullanarak Danimarka'da 1991 ve 1998 tarihleri arasında doğan (500,000'in üstünde) tüm çocukların KKK aş1lama yaşları, aşılama tarihleri, aşı üzerinden geçen süre ve otizm gelişimi Madsen ve ark. (25), tarafından kayıt altına alınmış ve birbiri arasında bir ilişki bulunamamıştır. Çalışmamızda elde ettiğimiz canlı virüs aşısının otizme sebebiyet verdiği olgusunun otizmli ebeveynlerde yüksek oranda kabul edilmesinin sebebi eğitim durumlarının kontrol grubuna oranla daha düşük olmasıyla açıklanabilir.

Detaylı anket çalışmamızın verilerinde görüldüğü üzere otizmli çocuğa sahip ebeveynler aşıların içerikleri ve otizme neden olup olmadıkları konusunda yeterli ve doğru bilgi sahibi olmamakla birlikte; çalışma ve eğitim durumu, aylık gelir düzeyi gibi faktörlere bağlı olarak fikirleri üzerinde olumlu etki oluşturabilecek çeşitli bilimsel araştırmalara ulaşamamaktadırlar. $\mathrm{Bu}$ durum onları çevrelerinden duydukları asılsız bilgilere itibar etmeye mecbur bırakır, bir felakete yol açabilir ve ebeveynlerinin yanlış endişeleri üzerine aşılanamayan çocuklardan oluşmuş bir toplum meydana gelebilir. Aşı ve otizm arasında bir nedensellik ilişkisi olup olmadığı konusunda hekimler ve sağlık çalışanları tarafından özellikle otizmli ailelerin sıklıkla bilgilendirilmesi, aşı ve otizm bağlantısının olmadığını kanıtlayan yayınların, sade ve anlaşı1ır şekilde yaygınlaştırılması ve arttırılmasına önem verilmelidir.

\section{Teșekkür}

$\mathrm{Bu}$ çalışmanın gerçekleştirilmesinde otizmli ailelerle iletişim kurabilmemizde bize her türlü desteği sağlayan;

DIYYODER (Diyarbakır Otizmliler Yardımlaşma Derneği)'e

KODER (Konya Otizm Uygulama Araştırma ve Dayanışma Derneği)'e,
Konya SOBE Vakfi'na,

OTEF (Otizm ve Engelli Dernekleri Fedarasyonu)'e,

SODER (Samsun Otizmli Çocuklar Derneği)' ne,

Bursa Yenigün Özel Eğitim Merkezi’ne,

teşekkürü bir borç biliyor ve şükranlarımızı sunuyoruz.

\section{Kaynaklar}

1.American Psychiatry Association. Diagnostic and Statistical Manual of Mental disorders-DSM-5, 2013, Washington, USA.

2.Prevalence of Autism Spectrum Disorder Among Children Aged 8 Years Autism and Developmental Disabilities Monitoring Network, 11 Sites, United States. 2016 https:/ www.cdc.gov/mmwr/volumes/69/ss/ss6904a1.htm?scid=ss6904a1w

3.Chaste P, Roeder K, Devlin B. The Yin and Yang of Autism Genetics: How Rare De Novo and Common Variations Affect Liability. Annu Rev Genomics Hum Genet, 2017; $18: 167-87$

4.Colvert E, Tick B, McEwen F et al. Heritability of Autism Spectrum Disorder in a UK Population-Based Twin Sample. JAMA Psychiatry; 2015;72(5):415-23.

5.M Lampi K, Hinkka-Yli-Salomäki S, Lehti V, et al. Parental Age and Risk of Autism Spectrum Disorders in a Finnish National Birth Cohort. J Autism Dev Disord, 2013;43(11):2526-35.

6.V Ratajczak H. Theoretical Aspects of Autism: Causes A Reviev. J Immunotoxicol; 2011;8(1):68-79.

7.O'Connell KS, McGregor NW, Lochner C, Emsley R, Warnich L. The Genetic Architecture of Schizophrenia, Bipolar Disorder, Obsessive-Compulsive Disorder and Autism Spectrum Disorder. Mol Cell Neurosci; 2018;88:300-7.

8.Keller R, Basta R, Salerno L, Elia M. Autism, Epilepsy, and Synaptopathies: A Not Rare Association. Neurol Sci; 2017;38(8):1353-61.

9.Geier DA, Geier MR. An Assessment of the Impact of Thimerosal on Childhood Neurodevelopmental Disorder. Pediatr Rehabil, 2003;6(2):97-102.

10.Geier DA, Geier MR. Neurodevelopmental Disorders Following Thimerosal-Containing Childhood Immunizations: A Follow-Up Analysis. Int J Toxicol 2004;23(6):369-76.

11.Hviid A, Vinsløv Hansen J, Frisch M, Melbye M. Measles, Mumps, Rubella Vaccination and Autism: A Nationwide Cohort Study. Ann Intern Med; 2019;170(8):513-20.

12.World Health Organization, MMR and Autism. https://www.who.int/vaccine safety/ committee/topics/mmr/Dec 2002/en/

13.Özdemir İN. Ebeveynlerin Cocukluk Cağı Așılarına Karșı Bilgi Tutum ve Davranışlar1, Marmara Üniversitesi Sağlık Bilimleri Enstitüsü, Yüksek Lisans Tezi, 2017, İstanbul. (Danışman: Doç. Dr. Hasibe Kadıŏlu)

14.Çalıklar, Ö, Kadıoğlu H. Validity and reliability of the Turkish Version of the Healthy Family Parenting Inventory. J Psychiatric Nurs, 2020;11(1): 49-56.

15.Price CS, Thompson WW, Goodson B, et al. Prenatal and infant exposure to thimerosal from vaccines and immunoglobulins and risk of autism. Pediatrics 2010;126(4):656-64.

16.Farrington CP, Milner E, Taylor B. MMR and autism: further evidence agaist a casual association. Vaccine 2001;19:3632-5.

17.Zerbo O, Modaressi S, Goddard K, et al. Vaccination patterns in children after autism spectrum disorder diagnosis and in their younger siblings; JAMA Pediatr. 2018;172(5):469-75

18.Çıkar S, Güner PD. Annelerin Çocukluk Çă̆ı Așıları Hakkındaki Bilgi, Davranış ve Tutumları ve Aşı Reddi Nedenleri: Nitel ve Nicel Bir Araştırma. Ankara Med J, 2020;(1):180-95.

19.Benin AL, Wisler-Scher DJ, Colson E, Shapiro ED, Holmboe ES. Qualitative analysis

Keşli ve ark. 
of mothers' decision-making about vaccines for infants: the importance of trust. Pediatrics 2006;117(5):1532-41.

20.Wakefield AJ, Murch SH, Anthony A, et al. Ileal-lymphoid-nodular hyperplasia, nonspecific colitis, and pervasive developmental disorder in children. Lancet 1998;351:63741.

21.DeStefano F, Price CS, Weintraub ES. Increasing exposure to antibody-stimulating proteins and polysaccharides in Vaccines Is not associated with risk of autism. J Pediatr 2013;163:561-7.

22.Madsen KM, Lauritsen MB, Pedersen CB, et al. Thimerosal and the occurence of autism: negatif ecological evidence from Danish population-based data. Pediatrics. 2003 12(3):604-6.

23.Hornig M, Briese T, Buie T, et al. Lack of association between measles virus vaccine and autism with enteropathy: A case-control study. PLoS One. 2008; 3(9): e3140. doi: 0.1371/journal.pone. 0003140

24.Taylor B, Miller E, Farrington CP, et al. Autism and measles, mumps, and rubella vaccine: no epidemiological evidence for a causal association. Lancet 1999;353:2026-29.

25.Madsen KM, Hviid A, Vestergaard M, et al. A population-based study of measles, mumps, and rubella vaccination and autism. N Engl J Med 2002;347(19):1477-82. 